\title{
Investigation on a Direct Injection Diesel Engine fuelled with blends of Waste Plastic Oil with a Three hole Fuel Injection Nozzle
}

\author{
[Dr. P. Ravi Kumar, M. Vijay Kumar, Dr. A. Veeresh Babu]
}

\begin{abstract}
Plastics have been one of the fastest growing materials due to versatility, wide range of applications and relatively at low. As the duration of useful life of plastic products is relatively small, a vast plastics waste stream is creating a serious environmental problem. Disposal of post-consumer plastics is being a serious constraint, a considerable demand for alternatives to disposal or land filling. Among the alternatives, production of liquid fuel would be a better alternative as the calorific value of plastics is comparable to that of fuels, around 40 $\mathrm{MJ} / \mathrm{kg}$. Other properties of the oil derived from waste plastics were also similar to the petroleum-based diesel. In the present work, blends of $20 \%, 40 \%, 60 \%, 80 \%$ Waste Plastic Oil (WPO) with diesel and $100 \%$ WPO are considered to investigate the performance, and emission characteristics in an existing diesel engine. For better understanding of the results, an injection time of 230 BTDC, 200 bar fuel injection pressure, and a 3 holes injector is used throughout the investigation. Some better performance and emission characteristics were observed from all the blend ratios. However, 20\% WPO and $80 \%$ diesel blend gave better results as compared to other waste plastic oil blends.
\end{abstract}

Keywords-Diesel, Wate Plastic Oil, Biodiesel, CI Engine, 3 holes fuel injector nozzle, Exhaust Analysers.

\section{Introduction}

Biodiesel is an alternative fuel similar to conventional or "fossil" diesel. Biodiesel meets most of chemical /physical standard of petro-diesel \& being plant based, it does not emit Sulphur on burning \& are non-toxic, non-polluting, biodegradable \& environment friendly. With no sulphurdioxide emission \& unburn hydro-carbons, biodiesel is an ideal fuel for heavily polluted cities. Biodiesel derived from the tree borne oil \& fats of plants like Jatropha Curcas, Sunflower, Rapeseeds, Palm, and Karanj etc. can be used as a substitute or an additive to petro-diesel.

Dr. P. Ravi kumar

Professor, NIT Warangal, Telangana, INDIA .

M. Vijay kumar

Research Scholar, NIT Warangal, Telangana, INDIA.

Dr. A. Veeresh Babu

Assistant professor, NIT Warangal, Telangana, INDIA.
Biodiesel can also be processed from animal fats, waste plastics \& vegetable oils (edible and non-edible oils). As an alternative fuel, biodiesel can provide power similar to conventional petro -diesel \& this can be used safely in diesel engines without any modification of the currently used diesel engines. Like Mercedes, Daimler Chrysler \& other renowned Automobile manufacturers like Mahindra \& Mahindra, Tata Motors in India have by now extended the engine warranty on the use of biodiesel in their vehicle.

\subsection{Waste plastic Oil}

Plastics are non-biodegradable polymers mostly containing carbon, hydrogen and a few other elements. According to a nationwide survey conducted in India in the year 2000, approximately 6000 tonne of plastic wastes were generated in every day and only $60 \%$ of it was recycled. In India alone, the demand for plastics is about 8 million tonne per year. More than 10,000 metric tonne / day production is from India and balance is imported from other countries. Most of plastics are recycled and sometimes it is not recycled due to lack of sufficient market value. Of the waste plastics not recycled, about $43 \%$ is polyethylene and most of them are in the form of containers and packaging materials.

The most attractive technique of chemical feedstock recycling is pyrolysis [1]. Thermal cracking or thermal pyrolysis involves the degradation of the polymeric materials by heating in the absence of oxygen. Different researchers [24] have studied the effect of temperature and the type of reactor on the pyrolysis of waste High Density Polyethylene (HDPE). The most common catalysts used in this process are: zeolite, alumina, silica-alumina, FCC catalyst, reforming catalyst [5-11]. Number of studies reported on the production of waste plastic oil at various scales and with varying success [12\&13]. The waste plastic oil has compared with the petroleum products and found to be suitable as a fuel in compression ignition engines [14].

\subsection{Fuel Injector}

The fuel injection system is the most vital component in the working of CI engine. The engine performance, power output, economy, etc. is greatly dependent on the effectiveness of the fuel injection system. The injection system has to perform the important duty of initiating and controlling the combustion process. Fuel is atomized into very fine droplets when it is being injected into the combustion chamber towards the end of the compression stroke by injector nozzle. 
Proc. of the Intl. Conf. on Advances in Applied science and Environmental Technology - ASET 2015. Copyright (C) Institute of Research Engineers and Doctors, USA .All rights reserved.

ISBN: 978-1-63248-040-8 doi: 10.15224/ 978-1-63248-040-8-93

Here by increase in the number of holes and the size of the nozzle, the thermal efficiency was decreased, but the performance increases[15]. The injector nozzle hole size and number included $340 * 2(340 \mu \mathrm{m}$ diameter holes with 2 holes in the nozzle), $240 * 4,200 * 6$, and $170 * 8$ among all of these injector nozzle holes, with biodiesel fuel in diesel engine, the brake specific fuel consumption (BSFC) increased than diesel fuel for four hole nozzle. However, $\mathrm{CO}, \mathrm{SO}, \mathrm{HC}$ decreases and NOx emissions increases due to higher temperature generate in engine [16]. Standard 3 holes nozzle and 210 bar injection pressure yielded lowest brake specific fuel consumption. Also, it was observed that for the same number of holes, small size hole nozzle at any given injection pressure yielded better performance. This is indicating the fact that the smaller nozzle requires higher injection pressure to ensure complete combustion and to bring down fuel consumption [17].

\section{Fuel Properties}

The major properties of the fuels have shown in below Table 2.1.

TABLE 2.1. PROPERTIES OF BIODIESEL BLENDS

\begin{tabular}{|c|c|c|c|c|c|c|}
\hline Property & Diesel & WPO & $\begin{array}{c}\text { WPO } \\
\mathbf{2 0}\end{array}$ & $\begin{array}{c}\text { WPO } \\
\mathbf{4 0}\end{array}$ & $\begin{array}{c}\text { WPO } \\
\mathbf{6 0}\end{array}$ & $\begin{array}{c}\text { WPO } \\
\mathbf{8 0}\end{array}$ \\
\hline $\begin{array}{c}\text { Density at } \\
30^{\circ} \mathrm{C}\end{array}$ & 820 & 808 & 817 & 813 & 812 & 810 \\
\hline $\begin{array}{c}\text { Kinematic } \\
\text { viscosity } \\
\text { at } 40^{\circ} \mathrm{C} \\
\left(\mathrm{m}^{2} / \mathrm{sec}\right)\end{array}$ & 2.07 & 1.04 & 1.93 & 1.79 & 1.61 & 1.23 \\
\hline $\begin{array}{c}\text { Calorific } \\
\text { value } \\
(\mathrm{KJ} / \mathrm{Kg})\end{array}$ & 43800 & 42201 & 43480 & 43160 & 42840 & 42520 \\
\hline $\begin{array}{c}\text { Sulphur } \\
\text { content } \\
(\%)\end{array}$ & $<0.045$ & $<0.030$ & - & - & - & - \\
\hline $\begin{array}{c}\text { Flash } \\
\text { point }{ }^{\circ} \mathrm{C}\end{array}$ & 50 & 42 & - & - & - & - \\
\hline $\begin{array}{c}\text { Fire point } \\
{ }^{0} \mathrm{C}\end{array}$ & 56 & 45 & - & - & - & - \\
\hline
\end{tabular}

\section{Experimental Setup and Procedure}

\subsection{Engine test}

A single cylinder four stroke water cooled diesel engine developing a power output of $3.7 \mathrm{KW}$ i.e. $5 \mathrm{HP}$ at rated speed of $1500 \mathrm{rev} / \mathrm{min}$ is used for the work. The specifications of the engine are shown in Table 3.1. The Schematic of the experimental setup is shown in Fig. 3.1. A DC shunt dynamometer is used for loading the engine.

A DC shunt dynamometer is used for loading the engine. The fuel flow rate has measured by volume through a burette. The experiment has been conducted to run at constant speed of $1500 \mathrm{rpm}$, compression ratio of $16.5: 1$, injection pressure of 200 bar and with a 3 hole injector nozzle.
TABLE 3.1. ENGINE SPECIFICATIONS

\begin{tabular}{|c|c|}
\hline Make & Kirloskar engines Ltd. \\
\hline Cooling system & Water cooled \\
\hline No. of cylinder & 1 \\
\hline Type & Direct injection, Four stroke \\
\hline Bore $\times$ stroke $(\mathrm{mm})$ & $80 \times 110$ \\
\hline Compression ratio & $16.5: 1$ \\
\hline Rated power $(\mathrm{kW}-\mathrm{HP})$ & $3.7 \mathrm{~kW}-5 \mathrm{HP}$ \\
\hline Rated speed & $1500 \mathrm{rpm}$ \\
\hline Swept volume & $553 \mathrm{cc}$ \\
\hline Fuel injection timing & $23^{\circ}$ before TDC \\
\hline Injection pressure & 200 bar \\
\hline Injector nozzle & 3 holes nozzle \\
\hline
\end{tabular}

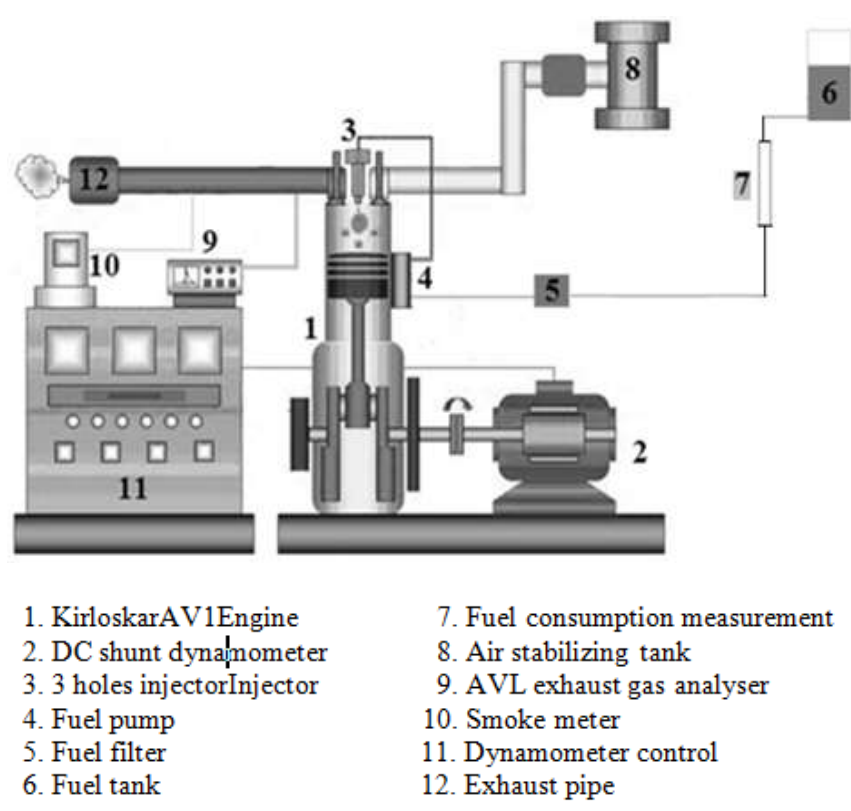

Fig. 3.1. Schematic of experimental setup

\subsection{Emission instrumentation}

\subsubsection{Exhaust Gas Emission Analyzer}

Exhaust gas emission analysis requires measurement of concentrations of regulated exhaust gases such as carbon monoxide (CO), unburned hydrocarbons (HC), carbon dioxide $\left(\mathrm{CO}_{2}\right)$ in the engine exhaust. AVL digas 444 gas analyzer was used for exhaust gas measurement.

\subsubsection{Smoke Opacity Measurement}

The opacity of the exhaust gas is measured by Hartridge Smoke meter. The smoke opacity quantifies the amount of particulate matter present in the engine exhaust. The Bosch smoke meter usually consists of a piston type sampling pump and a smoke level measuring unit. Two separate sampling probes were used to receive sample 
Proc. of the Intl. Conf. on Advances in Applied science and Environmental Technology - ASET 2015.

Copyright (C) Institute of Research Engineers and Doctors, USA .All rights reserved.

ISBN: 978-1-63248-040-8 doi: 10.15224/ 978-1-63248-040-8-93

exhaust gases from the engine, for measuring emission and smoke intensity separately. The filter paper of $4.5 \mathrm{~cm}$ diameter was used to collect smoke samples (from the engine) through the smoke sampling pump for measuring the Bosch Smoke opacity.

\subsection{Experimental procedure}

Necessary modifications and instrumentation of test engine was done and the experiments were performed as per to the objectives. Initially experiment has performed on the conventional CI engine at an engine speed of $1500 \mathrm{rpm}$ with five different engine loads, with constant $23^{\circ}$ bTDC injection timing, three holes nozzle injector, 200 bar injection pressure and 16.5:1 compression ratio with diesel as fuel to generate baseline data. Then experiments have conducted with WPO 20, WPO 40, WPO 60, WPO 80 and WPO as fuel with the same engine setup and above procedure. Obtained results of WPO blends compared for the performance and emission characteristics of diesel fuel.

\section{Results and Discussions}

\subsection{Brake specific fuel consumption}

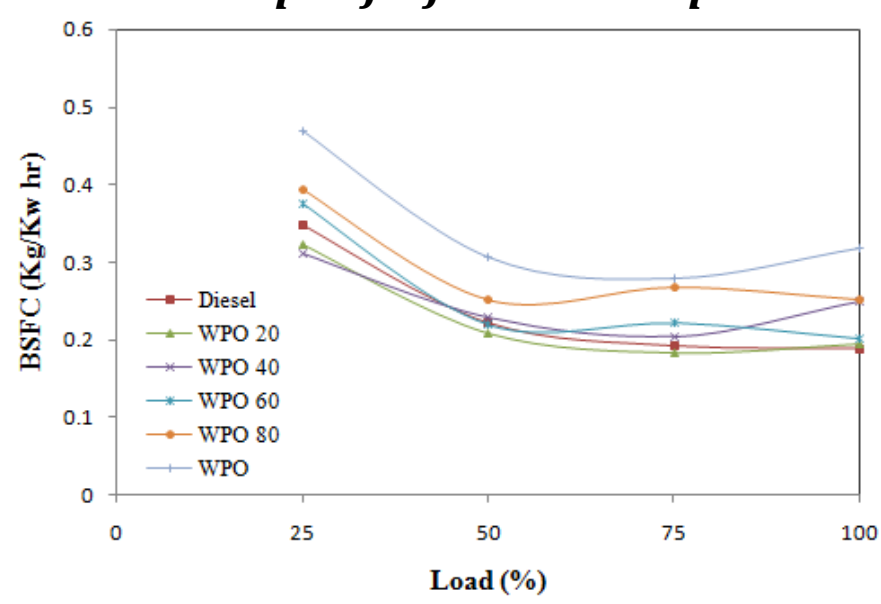

Fig. 4.1 Comparison of brake specific fuel consumption with load

The brake specific fuel consumption (BSFC) gives value that is more reliable when two different fuels of different heating values and densities blend each other. Figure 4.1 shows the comparison of the brake specific fuel consumption of WPO-diesel blend with diesel for 3 holes nozzle fuel injector. Among all WPO 20 has good BSFC. It can also see that BSFC is higher with increase in the concentration of WPO in WPO-Diesel blend. This behavior may be due to low calorific value of WPO-Diesel blends. Here the viscosity and density of fuel leads to decrease the BSFC.

\subsection{Brake thermal efficiency}

The below Fig. 4.2 shows the variation of brake thermal efficiency with load for WPO-diesel blends with 3 holes fuel injector nozzle. The brake thermal efficiency is $19.02 \%$ at full load for diesel. However, when the engine fueled with WPO- diesel blends such as WPO 20, WPO 40, WPO 60, WPO 80 and WPO it has given the lower thermal efficiencies of $18.45 \%, 14.37 \%, 17.82 \%, 14.27 \%$ and $11.29 \%$ respectively at full load. Also observed from the Fig. 4.2 that waste plastic oil blends shows the lower brake thermal efficiency. This is due to lower calorific value of WPO-diesel blends than diesel. Further, among all the blends, WPO 20 has higher brake thermal efficiency may due to lower viscosity.

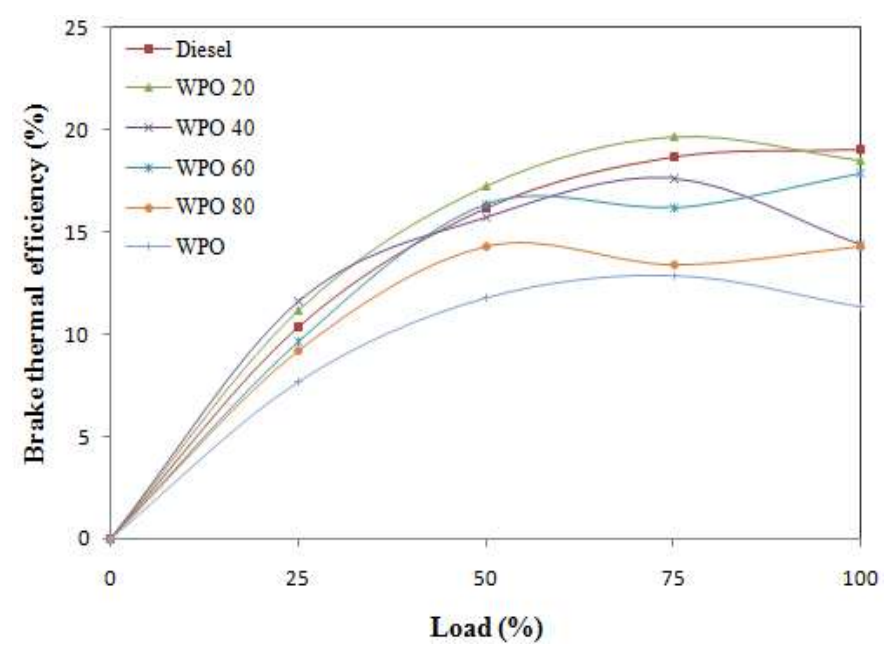

Fig. 4.2 Comparison of brake thermal efficiency with load

\subsection{HC emissions}

Unburned fuel is the main reason for hydrocarbon emission. Unburned hydrocarbon is a useful measure of combustion inefficiency. The variation of unburned hydrocarbon with load for 3 holes nozzle for tested fuels is shown in Figure 4.3. The hydrocarbon emission is decreasing with increase in the load. HC varies from 31 PPM at low load to 24 PPM at full load for diesel fuel, and it varies from 24 PPM at low load to 31 PPM at full load for WPO 60. Similarly, for WPO 80 it varies from 20 PPM at low load to 38 PPM at full load, for WPO it varies from 43 PPM to 50 PPM.

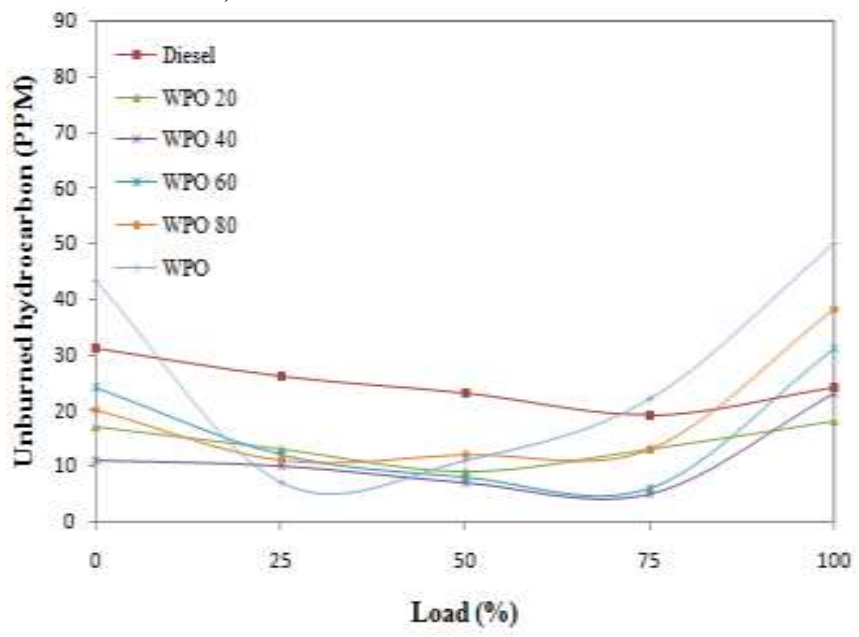

Fig. 4.3 Comparison of Unburned hydrocarbon emissions with load 
Proc. of the Intl. Conf. on Advances in Applied science and Environmental Technology - ASET 2015.

Copyright (C) Institute of Research Engineers and Doctors, USA .All rights reserved.

ISBN: 978-1-63248-040-8 doi: 10.15224/ 978-1-63248-040-8-93

The higher HC emission in blend compared to diesel has attributed to the reason that the viscosity of WPO-DF blends decrease with increase in concentration of WPO. Hence, the fuel spray for WPO-Diesel blends in case of 3 holes might have impingement on the wall due to which hydrocarbon remain along the cylinder wall which results in higher level of unburned hydrocarbon. For WPO 20 the unburned hydrocarbons reduced remarkably due to the oxygen present in the biodiesel.

\subsection{Carbon monoxide emissions}

The variation of carbon monoxide with load for 3 holes fuel injector is shown in Figure 4.4. Carbon monoxide emission is mainly due to the lack of oxygen, poor air entrainment, mixture preparation and incomplete combustion during the combustion process.

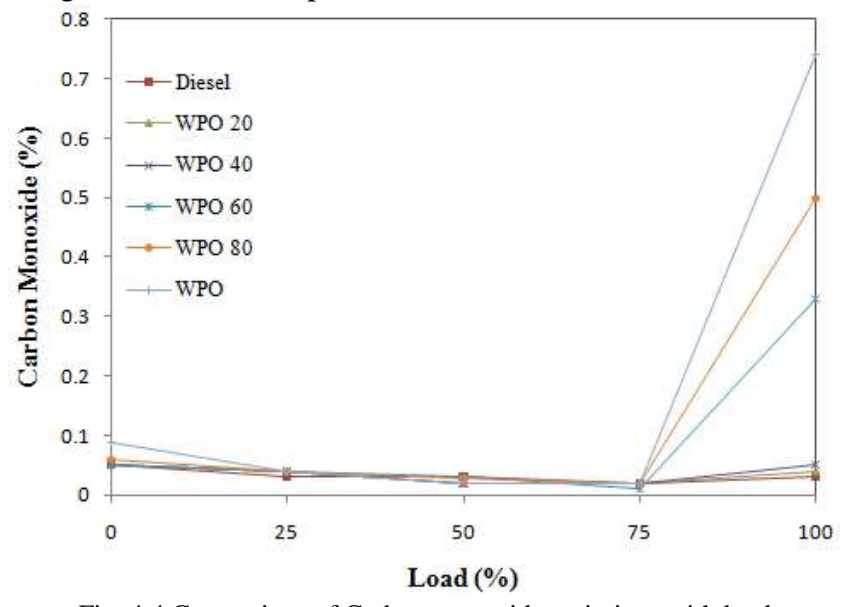

Fig. 4.4 Comparison of Carbon monoxide emissions with load

$\mathrm{CO}$ emission is toxic and must be controlled. It is an intermediate product in the combustion of a hydrocarbon fuel, so its emission results from incomplete combustion. The $\mathrm{CO}$ emission varies from $0.05 \%$ at low load to $0.03 \%$ at full load for diesel. For WPO 60, it varies from $0.05 \%$ at low load to $0.33 \%$ for full load, for WPO 80 it is 0.06 at low load to $0.5 \%$ at full load and from $0.09 \%$ at low load to $0.74 \%$ at full load for WPO. The results show that CO emission of waste plastic oil is higher than diesel especially at higher load and higher blend. The reason behind increased $\mathrm{CO}$ emission is incomplete combustion due to absence of oxygenated compounds in waste plastic oil. The drastic increase in $\mathrm{CO}$ emission at higher loads is due to higher fuel consumption.

The results show that $\mathrm{CO}$ emission of WPO-Diesel Fuel blends is higher than diesel that attributes to poor mixture preparation, local rich regions and absence of oxygenated compounds in waste plastic oil.

\subsection{Carbon dioxide emissions}

Fig. 4.5 illustrates the variation of carbon dioxide emission for various blends of waste plastic oil and diesel fuel at varying loads with 3 holes fuel injector nozzle.
Carbon dioxide occurs naturally in the atmosphere and is a normal product of combustion. Ideally, combustion of a $\mathrm{HC}$ fuel should produce only $\mathrm{CO}_{2}$ and water $\left(\mathrm{H}_{2} \mathrm{O}\right)$. The $\mathrm{CO}_{2}$ emission varies from $1.2 \%$ at low load to $2.7 \%$ at full load for diesel fuel. For WPO 60, it varies from $1.2 \%$ at low load to $2.5 \%$ at full load, from $1.2 \%$ at low load to $2.4 \%$ at full load for WPO 80. For WPO, it varies from $1.3 \%$ at low load to $2.2 \%$ at full load. The carbon dioxide emission for the blends is lower than diesel. This may be due to late burning of fuel leading to incomplete oxidation of $\mathrm{CO}$.

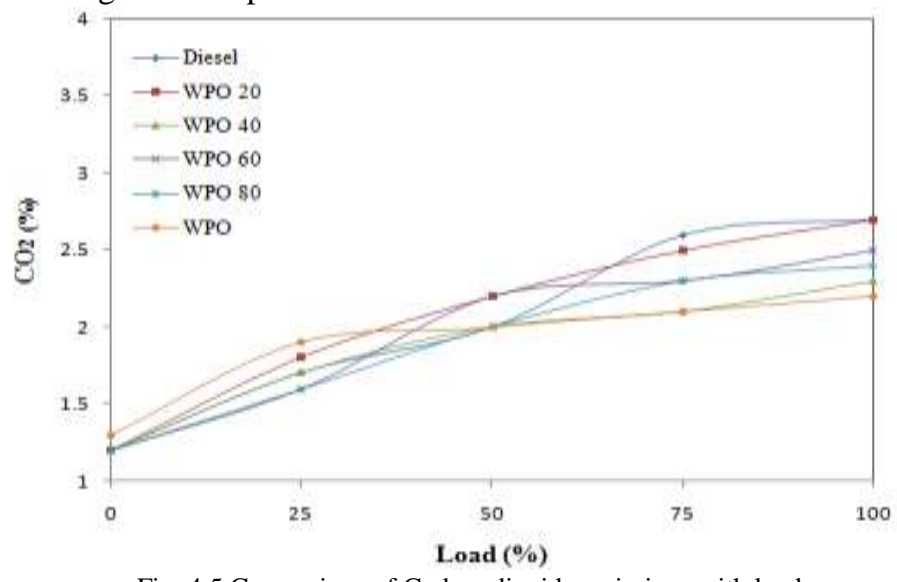

Fig. 4.5 Comparison of Carbon dioxide emissions with load

\subsection{Smoke emissions}

The variation of smoke emission with respect to load for different WPO-Diesel blend with 3 hole injector is shown in Fig. 4.6. The smoke value for Diesel at full load is $21 \%$, whereas for WPO 60, WPO 80, WPO it is $43 \%, 50 \%, 60 \%$ respectively. It is increasing with the increase in WPO concentration. It has known that soot precursors formed during premixed combustion phase and if, the premixed combustion phase is more pronounced there is more time available for carbon particles to combine with oxygen and combust properly. In the present case, the premixed combustion phase has less pronounced hence, more smoke at all the blends.

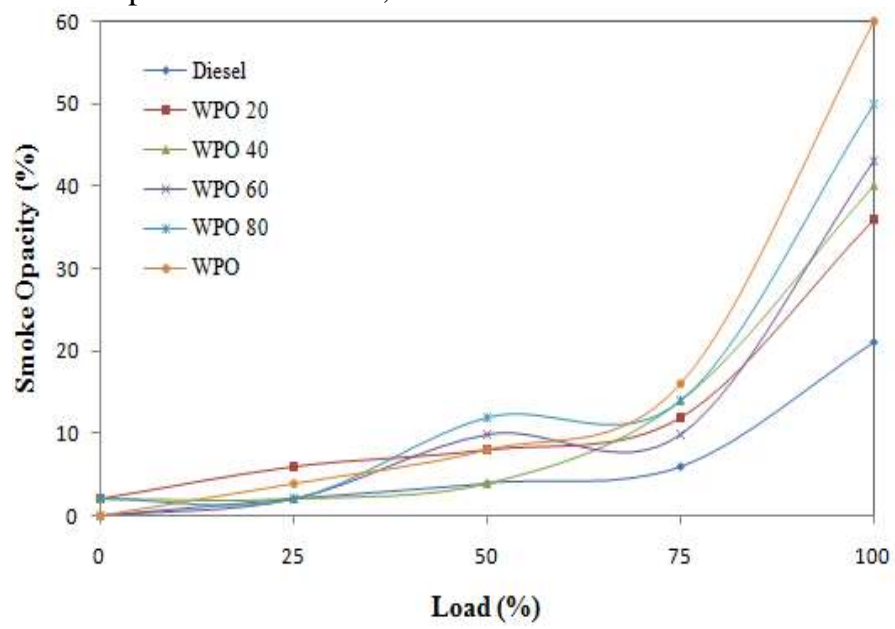

Fig. 4.6 Comparison of Smoke emissions with load 
Proc. of the Intl. Conf. on Advances in Applied science and Environmental Technology - ASET 2015.

Copyright (C) Institute of Research Engineers and Doctors, USA .All rights reserved.

ISBN: 978-1-63248-040-8 doi: 10.15224/ 978-1-63248-040-8-93

\section{v. Conclusions}

WPO and its blends with diesel were used in DI diesel engine and its effect on performance parameters and exhaust gas emissions were studied for 3 holes fuel injector. The following conclusions drawn based on experimental results and associated data analysis:

- Brake thermal efficiency decreased with increase in concentration of WPO.

- $\quad$ BSFC have reduced by reducing the concentration of WPO.

- $\quad \mathrm{HC}$ emissions have reduced at all loads condition for WPO 20.

- $\mathrm{CO}, \mathrm{HC}$ and smoke emissions increased with increase in concentration of WPO due to poor mixture preparation, local rich regions and absence of inherent oxygen in WPO.

- Emissions from waste plastic oil may be high, but if we consider its overall impact on the environment than it might be helping in the reduction of pollution.

The main advantage of WPO is engine can run with $100 \%$ waste plastic oil.

\section{vI. References}

[1] S, Singh RK. "Recovery of hydrocarbon liquid from waste high density polyethylene by thermal pyrolysis". Braz J Chem Eng 2011;28(04):659-67.

[2] Mani M, Nagarajan G. "Influence of injection timing on performance, emission and combustion characteristics of a DI diesel engine running on waste plastic oil". Energy 2009;34:1617-23.

[3] Wallis MD, Bhatia SK. "Thermal degradation of high density polyethylene in a reactive extruder". Polym Degrad Stabil 2007;92:1721-9.

[4] Consea JA, Font R, Marcilla A, Garcia AN. "Pyrolysis of polyethylene in a fluidized bedreactor". Energy Fuel 1994;8:1238-46.

[5] Walendziewski J, Steininger M. "Thermal and catalytic conversion of waste polyolefins". Catal Today 2001;65:323-30.

[6] Beltrame PL, Carniti P, Audisio G, Bertini F. "Catalytic degradation of polymers". Part II - Degradation of polyethylene. Polym Degrad Stabil 1989;26:209-20.

[7] Bagri R, Williams PT. "Catalytic pyrolysis of polyethylene". J Anal Appl Pyrol 2002;63:29-41.

[8] Venuto PB, Habib ET. "Fluid catalytic cracking with zeolite catalysts". New York: Marcel Dekker Inc.; 1979.

[9] Sharratt PN, Lin YH, Garforth AA, Dwyer J. "Investigation of the catalytic pyrolysis of high-density polyethylene over a HZSM-5 catalyst in a laboratory fluidized-bed reactor". Indus Eng Chem Res 1997;36(5):118-24.

[10] Miskolczi N, Bartha L. "Investigation of hydrocarbon fractions form waste plastic recycling by FTIR, GC, EDX RFS and SEC techniques". J Biochem Bioph Meth 2008;70:1247-53.

[11] Seo YH, Lee KH, Shin DH. "Investigation of catalytic degradation of high-density polyethylene by hydrocarbon group type analysis". J Anal Appl Pyrol 2003;70:383-98.

[12] Park JW, Kim JH, Seo G. "The effect of pore shape on the catalytic performance of zeolites in the liquid-phase degradation of HDPE". Polym Degrad Stabil 2002;76:495-501.

[13] Panda AK, Singh RK. "Catalytic performances of kaoline and silica alumina in the thermal degradation of polypropylene". J Fuel Chem Technol 2011; 39(3):198-202.

[14] Panda AK, Singh RK, Mishra DK. "Thermo-catalytic degradation of thermocol waste to value added liquid products". Asian J Chem 2012;24(12):5539-42.
[15] Mr. Lijo P Varghese et.al., "analysis of the effect of nozzle hole diameter on CI engine performance using karanja oil-diesel blends", International journal of mechanical engineering and technology, IF (2013):5.7731, volume 4,pp.79-88.

[16] Cenk Sayin et. al., "Influence of injector hole number on the performance and emissions of a DI diesel engine fueled with biodiesel diesel fuel blends", Applied Thermal Engineering 61 (2013), pp.121128.

[17] USV Prasad et al., "Influence of Fuel Injection Parameters of DI Diesel Engine Fuelled With Biodiesel and Diesel Blends", International Conference on Mechanical, Automobile and Robotics Engineering, Penang. Malaysia (2012), pp.261-264.

About Author (s):

\begin{tabular}{|l|l|}
\hline & $\begin{array}{l}\text { Dr. P. Ravi kumar } \\
\text { Professor in Mechanical Engineering } \\
\text { Department, } \\
\text { NIT Warangal-506004, Telangana, India. }\end{array}$ \\
\hline $\begin{array}{l}\text { M. Vijay kumar, } \\
\text { Ph.D Research Scholar Mechanical } \\
\text { Engineering Department, } \\
\text { NIT Warangal-506004, Telangana, India. }\end{array}$ \\
$\begin{array}{l}\text { Dr. A. Veeresh Babu, } \\
\text { Assistant professor in Mechanical } \\
\text { Engineering Department, } \\
\text { National Institute of Technology Warangal, } \\
\text { Warangal -506004, Telangana, India. }\end{array}$ \\
\hline
\end{tabular}

